ADDIN, Volume 13, Number 2, August 2019

\title{
Religion in the Conflict Flows
}

\section{Fajar Syarif}

Institut Ilmu Al-Qur'an (IIQ) Jakarta, Indonesia

fajarsyarif@gmail.com

\begin{abstract}
This research analyzes the issue of religion in understanding multiple realities. So it needs to be explained how religion can be one of the triggers of the problem and eventually become tyrants of other religions or beliefs. The problem that is limited in this study is that it relates to religion which is limited to the reality of conflicts that occur, as long as the conflict is published; both through research and through mass media. Furthermore, this research tries to look at the background of the understanding of diversity that occurs in society, so that it can be explained how it exists in interreligious relations in order to be in line. Religious expression among religious followers can influence patterns of integration and conflict. It will increase and become a trigger for conflict when it relates to the factors of economic and political inequality both locally, nationally, and even the constellation that is originally reasonable in the community, then strengthens and becomes clear, especially in society so that conflicts arise. Social integration can be a conflict resolution if maintained through bonds among citizens and social organizations that cross primordial boundaries.
\end{abstract}

Keywords: Religious Conflict, Public Space, Social Integration.

\section{Abstrak}

AGAMA DALAM ARUS KONFLIK. Penelitian ini menganalisis persoalan agama dalam memahami realitas yang majemuk. Perlu diuraikan bagaimana agama bisa menjadi salah satu pemicu 
permasalahan dan akhirnya menjadi tiran terhadap agama atau keyakinan yang lain. Permasalahan yang akan menjadi batasan dalam penelitian ini ialah berhubungan dengan agama yang dibatasi pada realitas konflik yang terjadi, sepanjang konflik tersebut terpublikasi, baik melalui penelitian maupun melalui media massa. Selanjutnya kajian dalam artikel ini melihat latar pemahaman keagaman yang terjadi pada masyarakat, sehingga dapat dipaparkan pemahaman keagaman bagaimana yang seharusnya dalam hal hubungan antar agama sehingga dapat seiring dan sejalan. Ekspresi agama di kalangan pengikut agama dapat memengaruhi pola integrasi dan konflik. Ini akan meningkat dan menjadi pemicu konflik ketika hal itu berkaitan dengan faktor-faktor ketidaksetaraan ekonomi dan politik, baik lokal, nasional, dan bahkan konstelasi yang semula masuk akal di masyarakat, kemudian menguatkan dan menjadi jelas, terutama di masyarakat sehingga timbul konflik. Integrasi sosial dapat menjadi resolusi konflik jika dipertahankan melalui ikatan di antara warga dan organisasi sosial yang melintasi batasbatas primordial.

Kata Kunci: Konflik, Agama, Ruang Publik, Integrasi Sosial.

\section{A. Introduction}

Shonhaji in his research stated that religion can be a unifying factor, as it can also be easily misused as a divisive tool. Religion on the one hand creates a common bond, but on the other hand, that alone is not enough to create a feeling of belonging to a group or social entity. Thus, religion has two effects at once, namely a unifying effect and also a divisive effect. ${ }^{1}$ This was confirmed by Nicola in his research that religion often becomes the root of the conflict. ${ }^{2}$ In fact, Brian in his research revealed that in the global context, the involvement of religious elements in a series of conflicts not only increases the escalation of conflict but also causes conflicts

${ }^{1}$ Shonhaji, "Agama: Konflik dan Integrasi Sosial: Agama Jawa dalam Perspektif Clifford Geertz", al-Adyan: Jurnal Studi Lintas Agama 5, no. 1 (2010): 17-32.

${ }^{2}$ Nicola Colbran, "Realities and Challenges in Realising Freedom of Religion or Belief in Indonesia", The International Journal of Human Rights 14, no. 5 (2010): 678-704. 
that are not easy to solve. ${ }^{3}$ Sarah Rasmi, Timothy M. Daly, and Susan S. Chuang in their study said that combining two different cultures would lead to conflict and would also increase understanding of the solution to eliminate conflict. ${ }^{4}$

The mass media has launched the reality of Indonesian harmony often disturbed by a series of violent conflicts that are rife in various areas ${ }^{5}$ with a lot of fatalities. ${ }^{6}$ These communal conflicts not only disrupt national stability, but also threaten national integration. The national community which is thought of as a solid building, suddenly turns into a pseudo community which according to Benedict Anderson is no more limited to an imaginary community. ${ }^{7}$ This is actually the toughest challenge for Indonesia as

${ }^{3}$ Brian J. Grim, "Law and Social Conflict in the 21st Century: Findings from Sociological Research", Oxford Journal of Law and Religion 1, no. 1 (2012): 249-271.

${ }^{4}$ Sarah Rasmi, Timothy M. Daly, and Susan S. Chuang, "Intergenerational Conflict Management in Immigrant Arab Canadian Families", Journal of Cross-Cultural Psychology 45, no. 7 (2017): 1.124-1.144.

${ }^{5}$ From data exposed through mass media, the riots occurred in Purwakarta (early November 1995), Pekalongan (end of November 1995), Tasikmalaya (September 1996), Situbondo (October 1996), Rengasdengklok (January 1997), Temanggung and Jepara (April 1997), Pontianak (April 1997), Banjarmasin (May 1997), Ende in Flores and Subang (August 1997), and Mataram (January 2000). See Jajat Burhanuddin and Arif Subhan, Sistem Siaga Dini terhadap Kerusuban Sosial (Jakarta: Balitbang Agama Depag RI and PPIM, 2000), 3. After 2000, riots continued to occur, such as in Ambon, Maluku, Kalimantan and other cities in Indonesia. See also C.A. Coppel, Violent Conflicts in Indonsia: Analysis, Represntation, Resolution (London: Routledge, 2005); Gery van Klinken, Communal Violence and Democratization in Indonesia: Small Town Wars (London: Routledge, 2007).

6 Estimated number of victims from each conflict, see Jacques Bertrand, Nationalism and Ethnic Conflict in Indonesia (New York: Cambridge University Press, 2004), 1. The number of communal conflicts can also be seen in Ashutosh Varshney, "Pattern of Collective Violence in Indonesia (1990-2003)", in United Nation Support Facility for Indonesian Recovery Report (Jakarta: Report UNSFIR, 2004), 25-27. About the percentage of types of conflicts in various regions see Karrie McLaughlin and Ari Perdana, "Conflict and Dispute Resolution in Indonesia Information from the 2006 Governance and Decentralization Survey", Indonesian Social Development Paper, no. 16 (2010), online edition can be seen on: www.conflictanddevelopment.org.

7 See Benedict Anderson, Imagined Communities: Reflections on the Origins and Spread of Nationalism (London and New York: Verso, 1991), 5 and 7. Further conception of nationality and nationalism can be read on Craig Calhoun, "Nationalism and Civil Society: Democracy, Diversity, and Self Determination", in Craig Calhoun, Social Theory and The Politics of Identity (Oxford: Blackwell Publisher, 1998), 312-321. About ethnic plurality and management strategies, read Muhammad Mahdi 'Ashur, at-Ta'addudiyah al-Itbniyab: 
a nation that is arranged in a multicultural, multiethnic, and multireligious that is easy to fall into disunity, if this nation fails to manage its structure properly.

Observing the various conflicts that have continued until now, the factor of religious sentiment is an important thing that cannot be ignored. ${ }^{8}$ Although ideologically there is no religion that teaches conflict and hostility, it is factually and historically recorded that the history of interreligious relations is often overwhelmed by tensions and violent conflicts. In the global context, even the involvement of religious elements in a series of conflicts will not only increase the escalation of conflict but also cause conflicts that are not easy to solve. ${ }^{9}$ Some conflicts with religious nuances have even caused some countries to break up into separate countries such as Pakistan and several countries in South Asia and a number of countries in the Balkan Gulf. ${ }^{10}$

Religion is the cause of all the major wars in the history of mankind. In fact, the causes of conflict are usually due to greed,

Idarah as-Sira'at al-Istirajiyat at-Taswiyah (Oman: al-Markaz al-'Ilmi li ad-Dirasat as-Siyasiyah, 2002).

${ }^{8}$ From the various riots that occurred in Indonesia, religious sentiments are often the most effective trigger element of the birth of violent conflicts that continue to this day.

9 Wlliem Vendley even mentioned that violent conflict has become synonymous with religious conflict. He cited endless conflicts such as Jews and Muslims in Palestine, Buddhism and Hinduism in Sri Lanka, Hindus and Muslims in India, Muslims and Christians in Nigeria, "West" Judeo-Christians and extremist Muslims in fighting terror and many cases of violence others who use the name religion. See Williem Vendley, "Kekuatan Agama-agama untuk Perdamaian", in Elza Peldi Taher, Merayakan Kebebasan Beragama: Bunga Rampai 70 Tahun Djohan Effendi (Jakarta: ICRP dan Kompas, 2009), 698. About quantitative data regarding religious involvement in social conflict see Brian J. Grim about quantitative data regarding religious involvement in social conflict see Brian J. Grim, "Law and Social Conflict in the $21^{\text {st }}$ Century: Findings from Sociological Research", Oxford Journal of Law and Religion 1, no. 1 (2012): 249-271.

${ }^{10}$ One example of the separation of Yugoslav nationality occurred in 1991, when Slovenia declared its independence which was followed by Croatia and Macedonia in 1992, and Boznia-Herzegovina in 1993. See Karel Steenbrink, "Does Comparison Help? The Disastrous Decade of Yugoslavia Seen from an Indonesian Perspective", in Chaidar S. Bamualim, Communal Conflict in Contemporary Indonesia (Jakarta: The Centre for Languages and Cultures IAIN Syarif Hidayatullah Jakarta and The Konrand Adenauer Foundation, 2003), 216-217. 
hatred, and ambition, but in an effort to sterilize them, emotions that indulge in one's own desires are often wrapped up in religious rhetoric. ${ }^{11}$ Religion is indeed considered a source of teachings of nobility and harmony. However, not infrequently arises between religious adherents. This reality must be realized, not as a tool for provocation, but it is hoped that the community must try to manage pluralism.

The presence of religion in public space in general can be seen from the spread of values, teachings and religious symbols to the community by utilizing public spaces, both real and virtual that are used jointly by the community to communicate and negotiate various ideas and interests, including views and religious interests. ${ }^{12}$ In the view of Hebermas, religion in the public space is required to release claims as the only ones having the authority to interpret and determine the legitimate way of life. ${ }^{13}$ When entering a public space, religion must be interpreted secularly based on the principle of rationality.

Habermas's view is influenced by the concept of DemocracyDeliberative $^{14}$ that the state and religion must be separated from

\footnotetext{
${ }^{11}$ Karen Armstrong, Campassion: 12 Langkah Menuju Hidup Berbelas Kasib (Bandung: Mizan, 2013), 10.

${ }^{12}$ Using Jurgen Habermas's perspective, the presentation and discourse of Islam in the public space, however, contains the political dimension of various social forces which seek to articulate publicly the interests of the state. See Sukron Kamil, Noorhaidi Hasan, and Irfan Abubakar, Islam di Ruang Publik: Politik Identitas dan Masa Depan Demokrasi di Indonesia (Jakarta: Centre for the Study of Religion and Culture [CSRC] UIN Syarif Hidayatullah Jakarta, 2011), 2 and 3.

${ }^{13}$ See F. Budi Hardiman, Ruang Publik: Melacak Partisipasi Demokratis dari Polis sampai Cyberspace (Yogyakarta: Kanisius, 2010), 230. About the concept of "Agama di Ruang Publik", Habermas wrote specifically about it in his book, Between Naturalism and Religion (New York: Polity Press, 2009), translated from the original book "Zwischen Naturalismus und Religion" in 2005. Specifically in the sub-title "Religion in The Public Sphere".

${ }^{14}$ Deliberative democracy in the sense of Habermas is an attempt to reconstruct the communication process in the context of a democratic state. Deliberative: consultation, weighing and deliberation. Deliberative democracy is a view adopted from the thinking of Habermas, a thinker from the Frankfrut School. The core of this view is how to activate individuals in society as citizens to communicate, so that communication that occurs at the level of citizens is able to influence public decision making at the level of
} 
their roles. Nevertheless, Habermas acknowledged that religion is a complete view of life or doctrine, but when taken into public space, its metaphysical doctrines must be explained rationally. ${ }^{15}$ Religion in the public space requires the existence of two-way communication or in Habermas's term referred to as practical discourse. ${ }^{16}$ In this process there is discussion in the public space by maintaining the space in a state of neutrality, because the foundation is rationality not religious doctrines that are individual piety. The doctrines are conveyed through language that can be accepted by everyone, so that there is a discourse process that leads to social piety. ${ }^{17}$

Religious conflicts are a type of conflict that is not easy to resolve, but that does not mean that the conflict cannot be managed properly. George Weige gives a balanced assessment that religion can be a source of conflict while also having creative potential that can serve as a strong guarantee for social tolerance, democratic pluralism and nonviolent conflict resolution. ${ }^{18}$ The condition is the willingness of religious followers to live and practice their religion in

the political system. In practice, deliberative democracy prioritizes the use of decisionmaking procedures that emphasize deliberation and problem solving through dialogue and exchange of experience between parties and citizens. Citizen participation is the core of deliberative democracy. See Jurgen Habermas, Religion in Public Sphere (New York: Polity Press, 2009), 125.

${ }^{15}$ F. Budi Hardiman, Ruang Publik: Melacak Partisipasi Demokratis dari Polis sampai Cyberspace (Yogyakarta: Kanisius, 2010), 121. See also Habermas's thoughts that were extracted by F. Budi Hardiman, Demokrasi Deliberatif (Yogyakarta: Kanisius, 2009), 74.

${ }^{16}$ See F. Budi Hardiman, Ruang Publik: Melacak Partisipasi Demokratis dari Polis sampai Cyberspace (Yogyakarta: Kanisius, 2010), 19. 120.

${ }^{17}$ See Jurgen Habermas, Religion in Public Sphere (New York: Polity Press, 2009),

${ }^{18}$ George Weige, "Religion and Peace an Argument Complexified", in Syeryl Brown and Kimber Schraub, Resolving Third Word Conflict: Challenge for New Era (Washington DC: US Institute of Peace Press, 1992), 173. A number of international institutions also pay great attention to the role of religion in conflict resolution and recommend it as part of the creation of cohesion and social integrase. Among Muslims, efforts to explore the role of religion in conflict resolution have also been carried out by a number of scholars, including among others; Ralph H. Salmi, Cesar Adib Majul, and George Kilpatrick Tanham, Islam and Conflict Resolution: Theories and Practices (Lanham: University Press of America, 2001); Mohammed Abu-Nimer, Non Violence and Peace Building in Islam: Theory and Practice (Florida: University Press of Florida, 2003). 
an adult, ${ }^{19}$ tolerant and pluralist manner. As revealed by Khaled Abou El Fadl that a tolerant and pluralist spirit of religious adherents will determine the style of understanding the sacred text of the religion tolerantly as well. ${ }^{20}$

Ahmad Syafi'i Ma'arif stated that it turns out that the Qur'an is more tolerant than the Muslims themselves. He criticized the attitude of Muslims who tend to be intolerant of religious beliefs, even though the Qur'an makes demands for it. This can happen because of a lack of tolerance in interpreting the true religion. ${ }^{21}$ Komarudin Hidayat and Muhammad Wahyuni Nafis revealed that the religion of the future is a religion that will be lived through humanity's actualization and is a place for expression and as a manifestation of the search for meaning in life. ${ }^{22}$

In order for such ideal conditions to be achieved, various efforts are needed so that religion truly plays a prophetic vision in elevating the dignity of modern humans. Increasing a culture of mutual respect and developing a tolerant attitude among religious followers through a culture of sincere dialogue and developing an attitude of cooperation on humanitarian issues in general is an important step to restore the function of religion as a pacifier in the

\footnotetext{
${ }^{19}$ Violent conflicts often arise as a result of religious leaders having what the Scoot Appleby calls "religious illiteracy" (an attitude of being shallow in interpreting religion). For more information see R.S. Appleby, The Ambivalence of the Sacred: Religion and Violence, and Reconciliation (New York: Rowman and Littlefield, 2000), 69.

${ }^{20}$ Khaled Abou El Fadl clearly stated that "The meaning of a holy text often depends on the moral of the reader. If the reader is intolerant and full of hatred, then this is the result of his interpretation of the text." Read more about Khaled Abou El Fadl, The Place of Tolerance in Islam (Boston: Beacon Press, 2002), 23. Elaboration of the principles of the Qur'an and Hadith concerning plurality (ta'addudiyat) can be read in the work of the brother of Hasan al-Banna and Jamal al-Banna, at-Ta'addudiyat fi Mujtama' Islami (Kairo: Dar al-Fikr al-Islami, 2001); Muhammad 'Imarah, at-Ta'addudiyab: ar-Ru'yah al-Islamiyyah wa at-Tahaddiyah al-Gharbiyyah (Mesir: Dar an-Nahdah, 1997); Ibrahim Kalin, "Mashadir atTasamuh wa 'Adam at-Tasamuh fi al-Islam", Majallah Adyan, 2009, 26-32.

${ }^{21}$ See Muhammad Qorib, "Pemikiran Ahmad Syafi'i Ma'arif Tentang Pluralisme Agama", Ph.D. Thesis, Universitas Islam Negeri (UIN) Syarif Hidayatullah Jakarta, 2012, 40.

${ }^{22}$ Komaruddin Hidayat and Muhammad Wahyuni Nafis, Agama Masa Depan: Perspektif Filsafat Perenial (Jakarta: Paramadina, 1995), 134-136.
} 
earth. In the context of Islamic studies, this effort is a challenge for Islamic intellectuals to creatively begin to orient the study of issues of individual piety to social piety. ${ }^{23}$ Such activities, on the one hand, will restore the role of religion to solve modern problems, and on the other hand can dynamize Islamic studies themselves. ${ }^{24}$

\section{B. Discussion}

\section{The Discourse on Religious Conflict in Society}

Religious conflicts that occur violently and sustainably are usually caused by vested interests that go into and on behalf of religious teachings. If this element of hidden interest has entered into a conflict with a religious face, it cannot be expected that the conflict will end. Religion in this case only becomes a "tool" for the interests of a person or group of people to achieve what they want. ${ }^{25}$ Tarmizi Taher ${ }^{26}$ and Wasisto Raharjo Jati ${ }^{27}$ concluded that religion is not the main source of conflict. There are more crucial problems that are at the root of conflict, namely social, political, and economic. But Sam Harris, Richard Dawkins, and Chistopher

${ }^{23} \mathrm{~A}$ complete description of this, see Hasan Hanafi, Dirasat Islamiyah (Kairo: Maktabah al-Anjilu al-Mishriyah, n.d.), 204. Meanwhile Amin Abdullah also mentions in detail, "The challenge of the word or contemporary Islamic theology and overall Islamic thought is to answer universal humanitarian issues, religious pluralism, environmental damage, strengthen national discipline, strengthen public morality." Read more in M. Amin Abdullah, Islamic Studies di Perguruan Tinggi: Pendekatan Integratif-Interkonektif (Yogyakarta: Pustaka Pelajar, 2006), 315.

${ }^{24}$ Academic activities like this in turn will answer Arkoun's critics who see the current kalam study as closed and static. See Muhammad Arkoun, al-Islam: al-Akblaq wa asSiyasah (Beirut: Markaz al-Inma' al-Qaumi, 1990), 172; about the rigidity critics of kalam, see Muhammad 'Abid al-Jabiri, Bunyat al-Aql al-'Arabi: Dirasab Tabliliyah Naqdiyah li Nudbum al-Ma'rifah fi ats-Tsaqafah al-'Arabiyah (Beirut: Markaz Dirasat al-Wihdah al-'Arabiyah, 1990), 497-498.

${ }^{25}$ Badan Penelitian dan Pengembangan Departemen Agama RI, Manajemen Konflik Umat Beragama (Jakarta: Proyek Peningkatan Kerukunan Hidup Umat Beragama dan Pusat Kerukunan Beragama Departemen Agama RI, 2003), 14.

${ }^{26}$ Tarmizi Taher, Menuju Ummatan Wasathan: Kerukunan Beragama di Indonesia (Jakarta: PPIM, 1998), 52.

${ }^{27}$ Wasisto Raharjo Jati, "Kearifan Lokal Sebagai Resolusi Konflik Keagamaan”, Walisongo 21, no. 2 (2013): 29-43. 
Hitchens firmly put religion as a source of problems that caused many conflicts. ${ }^{28}$

In sociology studies, religion can be interpreted as a social reality in which not only contains normatic teachings but contains other social variables such as adherents, interpretations of teachings, religious institutions and ideology. ${ }^{29}$

Religious conflict is defined as Rizal Panggabean as a competition concerning values, claims and identities involving religious issues framed in religious slogans or expressions. ${ }^{30}$ Franz Magniz Suseno calls religious conflicts in Indonesia as conflicts between citizens by analyzing emotions, hatred, and prejudice related to the collective identity of a primordial group, united by language, local culture, regional character, religion, ethnicity, and so on. Whereas religion is the strongest element in the collective identity of the community so that it easily creates conflict. ${ }^{31}$ Rafl Dahrendorf stated that conflict is an inherent omni-presence. Conflict is actually a natural phenomenon that accompanies patterns of human interaction throughout time. Not all conflicts take place through violence. The problem is when conflicts turn into violence or anarchy, especially by involving a large number of masses. The social harmony that has been built usually changes into chaos and creates social disintegration. ${ }^{32}$

${ }^{28}$ Charles Kimball, When Religion Becomes Evil (London: Harper Collins, 2003), 57; Sam Harris, The End of Faith: Religion, Terror, and the Future of Reason (Ohio: W.W. Norton and Company, 2004), 176; Christopher Hitchens, God Is Not Great: How Religion Poisons Everything (New York: Grand Central Publishing, 2007), 192; Sam Harris, Letter to a Christian Nation (New York: Vintage Books, 2008), 84; Richard Dawkins, The God Delusion (Orlando: Houghton Mifflin Harcourt, 2008), 120.

${ }^{29}$ See Elizabeth K. Nottingham, Agama dan Masyarakat: Suatu Pengantar Sosiologi Agama (Jakarta: Rajawali Press, 1990).

${ }^{30}$ Rizal Panggabean, Pola-pola Konflik Keagamaan di Indonesia (1990-2008) (Jakarta: Paramadina, 2009), 8.

${ }^{31}$ Franz Magniz Suseno, et al., Memahami Hubungan antar Agama (Yogyakarta: Elsaq Press, 2007), 13-16.

${ }^{32}$ Rafl Dahrendorf, Class and Class Conflict in Industrial Society (Stanford: Standford 
There are many theories that explain the causes of conflict. One of them is what was stated by Simon Fisher who mentioned several theories about the occurrence of conflict: First, public relation theory. This theory states that conflict occurs due to ongoing polarization, distrust, and hostility between different groups in society. Second, conflict negotiation theory. This theory assumes that conflicts occur by incongruous positions and differences in views about conflict by parties experiencing that conflict. Third, human needs theory—physical, mental, and social — that is not fulfilled or hindered. Security, identity, recognition, participation and autonomy are often the core of the conversation. Fourth, identity theory. This theory assumes that conflict is caused by threatened identity, which is often rooted in the loss of something or suffering in the past that is not solved. Fifth, intercultural misunderstanding theory. This theory assumes that conflict is caused by incompatibility in the ways of communication between different cultures. Sixth, conflict transformation theory. That conflict is caused by inclusion and injustice that arise as social, cultural and economic problems. ${ }^{33}$

Jacques Bertrand revealed that there are three major theories related to the phenomenon of the rise of violent conflict in Indonesia. First, it is an analysis that emphasizes the involvement of elites in Jakarta (their state, military and political opponents). This analysis is similar to conspiracy theories. But the analysis of the "conspiracy" theory model like this is not enough to successfully explain why so many people are involved so that the escalation of conflict continues to grow. Second, analysis that focuses on the involvement of local elites rather than national elites who are mutually competent. They, these local elites often mobilize the

University Press, 1959), 245-256; Muhammad Mahdi 'Ashur, at-Ta'addudiyah al-Ithniyah: Idarah as-Sira'at al-Istirajiyat at-Taswiyah (Oman: al-Markaz al-'Ilmi li ad-Dirasat as-Siyasiyah, 2002).

${ }^{33}$ Simon Fisher, Working With Conflict: Skills and Strategies for Action (London: Zed Books, 2000), 4. 
masses for their political interests. Religious sentiment is often used considering that religious identity is the most powerful group identity in the social structure. Third, is an approach that focuses on the suffering felt by local communities related to state policy. The case of riots in West Kalimantan, for example, occurred because ethnic Dayak felt excluded by state policies, so they did not have economic access and power in their own regions. Likewise what happened in Aceh, the conflict between the Free Aceh Movement (Gerakan Aceh Merdeka, GAM) and the central government was a form of resistance to state policies that were considered unfair. They feel disadvantaged by wealth management, all of which is sucked into the central government. The hatred of the Indonesian government, especially to Indonesian National Army (Tentara Nasional Indonesia, TNI), grew stronger especially since the enactment of Aceh as a Military Operation Area (Daerah Operasi Militer, DOM). ${ }^{34}$

Franz Magnis Suseno stated that ethnic-religious conflicts in Indonesia are caused by complex backgrounds. There are at least three factors. First, the influence of modernization and globalization that has entered the niche of Indonesian society. Modernization with its socialization and individualistic tendencies have contributed to the strengthening of communal conflicts in which the community is more determined by religious identity, language and general awareness of the region. Second, accumulation of hatred in society. Various stereotypes, stigma over other groups which all this time only revolve as hidden transcripts strengthen and at the right time appear on the surface. Individual hatred along with other hatreds led to collective hatred of all group members. The assumption that other groups or religions as infidels and as rivals continues to

${ }^{34}$ Jacques Bertrand, Nationalism and Ethnic Conflict in Indonesia (New York: Cambridge University Press, 2004), 6-7; Suprapto, Semerbak Dupa di Pulau Seribu Masjid: Kontestasi, Integrasi, dan Resolusi Konflik. Hindu-Muslim (Jakarta: Impressa, 2013), 35-36. 
strengthen so that it becomes strong ammunition as a trigger for riots. Third, the community has long been gripped in a culture of violence. Indonesian people are sick, considering that violence is often used as a way to solve problems. ${ }^{35}$

Basically conflict is something that naturally happens in social interactions and will always be part of the reality of life. Conflict is not always bad. On the one hand, conflict has a positive impact. Proponents of conflict theory from post-modernist groups such as Lewis Coser, Gorg Simmel, Ralf Dahrendrof, and Max Gluckman see conflict as having a positive side of making people aware of many problems, pushing toward the necessary changes, improving solutions, fostering enthusiasm, accelerating personal development, increase self-awareness, encourage psychological maturity, ${ }^{36}$ and usually conflicts that occur between groups can foster and increase the solidarity of the group's identity. For example, years of war in the Middle East have strengthened the identity of groups of Arab and Israel countries, or Protestants and Catholics in Northern Ireland. ${ }^{37}$ Although on the one hand there are those who view the conflict as necessary to stimulate attention, creativity, and prevent stagnation, it does not mean that the conflict must be allowed to happen or deliberately made happen. Every conflict that arises must be immediately suppressed and solved, because after all the conflict continues to have a negative impact, especially if the conflict leads

${ }^{35}$ See Franz Magnis Suseno, "Underlying Factors of Conflict between Ethnic and Religious Groups in Indonesia: Prevention and Resolution", in Chaidar S. Bamualim, Communal Conflict in Contemporary Indonesia (Jakarta: The Centre for Languages and Cultures IAIN Syarif Hidayatullah Jakarta and The Konrand Adenauer Foundation, 2003), 185-201.

${ }^{36}$ Simon Fisher, Working With Conflict: Skills and Strategies for Action (London: Zed Books, 2000), 4. Lewis Coser and Simmel have the same opinion that conflict does not only have a negative face. Conflict has a positive function on society through the social changes that result from it. See also Choirul Fuada Yusuf, Konflik Bernuansa Agama: Peta Konflik Berbagai Daerah di Indonesia 1997-2005 Jakarta: Badan Penelitian dan Pengembangan Kementerian Agama RI, 2013), 9.

${ }^{37}$ Argyo Demartoto, "Strukturalisme Konflik: Pemahaman Akan Konflik pada Masyarakat Industri Menurut Lewis Coser dan Rafl Dahrendrof”, Jurnal Sosiologi Dilema 24, no. 1 (2010): 192-223. 
to acts of violence. In addition, prolonged conflict will damage the order of social life. ${ }^{38}$

\section{Religious Expressions Among Religious Adherents}

Ira M. Lapidus stated that religion is the heart of its followers and is an essential component of their personal and political identity. Religion is the name for a primordial sentiment that gives meaning to its followers for its existence in a society. ${ }^{39}$ Thus, religion is a matter of life and death or based on the opinion of Paul Tillic, religion is the ultimate concern. ${ }^{40}$ So the attitude or diversity of religious adherents will be different from those of other religions, depending on how they place their religious position.

Frederich Heiler noted that religious conflict is driven by the religious expression of its adherents. Believers always contradict each other, even involving war and degrading other religious beliefs. Heiler also pointed out the facts of a number of atrocities committed by Confucianism against followers of Buddhism in China, the fate of Islamic missionaries in India, as well as the fate of expelling Jews from their congregations and gettho in medieval Christianity, ${ }^{41}$ and also the dark history of crusading between Islam and Christianity. Even in religions that are considered to be the most tolerant like Hindu, the issue of conversion is also a problem that disrupts social relations between humans. A Hindu who converts to Christianity,

\footnotetext{
${ }^{38}$ Raden Siti Fadilah Tohiriyyah, Konflik Muslim-Kristen: Studi Kasus Gereja Kristen Indonesia (GKI) Yasmin Bogor (Ciputat: Cinta Buku Media, 2016), 26-31.

${ }^{39}$ Ira M. Lapidus, A History of Islamic Societies (New York: Cambridge University Press, 1988), 915-916.

${ }^{40}$ Paul T. Illich, The Spiritual Situation in Our Technical Society (Georgia: Mercer University Press, 1988), 42; F. Forrester Church, The Essential Tillich: an Anology of The Writings of Paul Tillich (Chicago: University of Chicago Press, 1987), 32.

${ }^{41}$ Gettho is a kind of settlement or ethnic enclave for Jews who are usually identified with slums and poor places. Further explanation about discriminatory treatment of Jewish followers in America and Canada and interfaith conflicts can be read at Keith A. Roberts, Religion in Sociological Perspektive (Belmont: Wadsworth, 2004), 56-57.
} 
Islam or other religions, has been cut off from his family and castle, and is even considered lower than the pariah caste. ${ }^{42}$

George B. Grose and Benjamin J. Hubbard distinguish adherents of religion into three types: inclusive, exclusive, and pluralist. ${ }^{43}$ Terrence W. Tilley put forward four attitudes: exclusivism, inclusivism, pluralism, and particularism. ${ }^{44}$ While Raimindo Panikkar also stated that there were four attitudes: exclusivism, inclusivism, parallelism, and pluralism. ${ }^{45}$

a. Exclusivism

Exclusivism is the view and attitude that claims that the religion is the most correct. For this group, truth, salvation and various other virtues are only in the religion they adhere to. This view only recognizes the single truth, namely the religion they profess. Other religions are seen as not having the same truth nor offering safety. ${ }^{46}$

Exclusivism as an attitude, believes that their religion is the most correct. This is very evident in religions that have scriptures. The scriptures they have, are considered more superior than other religions. Arlodod Toynbe said that the three religions namely Jews, Christians and Islam had a tendency towards exclusivity as the ultimate owner of truth. ${ }^{47}$ This is slightly different from religion in India which still recognizes the similarities of manifestations of other religions. ${ }^{48}$

\footnotetext{
${ }^{42}$ Frederich Heiler, Prayer: a Study in the History and Psychology of Religion (Oxford: Oxford University Press, 1932), 23-26.

${ }^{43}$ George B. Grose and Benjamin J. Hubbard (eds.), The Abrabam Connection: a Jew, Christian, and Muslim in Dialoge (Notre Dame: Cross Cultural, 1994), 6.

${ }^{44}$ Terrence W. Tilley, Postmodern Theologies and Religious Diversity (Maryknoll, New York: Orbis Book, 1996), 158.

${ }^{45}$ Suprapto, Semerbak Dupa di Pulau Seribu Masjid: Kontestasi, Integrasi, dan Resolusi Konflik Hindu-Muslim (Jakarta: Impressa, 2013), 47.

${ }^{46}$ Raimundo Panikkar, The Intra-Religious Dialogue (Costa Mesa: Paulist Press, 1999), $18-24$.

${ }^{47}$ Arlnod Toynbe, A Study of History (Oxford: Oxford University Press, 1987), volume 1, 96.

${ }^{48}$ Suprapto, Semerbak. Dupa di Pulau Seribu Masjid: Kontestasi, Integrasi, dan Resolusi
} 
In the history of religions, exclusivity has been shaped in such a way as to produce dichotomous views, such as the division of "revelation and non-revelation religion", "samawi-ardl", and "semitic and non-semitic". 49 This kind of classification can be found in the works of Christian theologians, such as Thomas Aquinas, ${ }^{50}$ and Muslims such as Abdul Karim asy-Syahrastani. ${ }^{51}$ This type of classification is intended to strengthen the superiority of one religion to another.

b. Inclusivism

Inclusivism is a religious view and attitude that claims that their religion has truth and salvation that are more perfect than other religions. Being inclusive means that truth and salvation are not monopolies of certain religions, but are very likely to be found in other religions. ${ }^{52}$

Inclusivism does not mean not having a stance, but still believing that his religion is right, but at the same time also recognizing certain parts of other religions that contain truth. Inclusivism as a view is the opposite of exclusivism beginning to be developed in every religion.

Nurcholish Madjid is one of the figures who introduced and promoted inclusivism in religion. For him, adherents

Konflik Hindu-Muslim (Jakarta: Impressa, 2013), 47.

${ }^{49}$ Kautsar Azhari Noer, "Agama Langit versus Agama Bumi: Sebuah Telaah atas Klasifikasi Agama-agama”, Titik Temu: Jurnal Dialog Peradaban 3, no. 2 (2011): 72-96.

${ }^{50}$ Thomas Aquinas is a Christian theologian who first distinguished natural religion and revelation. See Kautsar Azhari Noer, "Agama Langit versus Agama Bumi: Sebuah Telaah atas Klasifikasi Agama-agama”, Titik Temu: Jurnal Dialog Peradaban 3, no. 2 (2011): 72-96.

${ }^{51}$ Asy-Syahrastani is the Asy'ari theologian who divided the world population into two broad categories namely: those who have religion or belief, and those who follow their passions and sects. See Muhammad Abdul Karim asy-Syahrastani, al-Milal wa an-Nihal, ed. Abdul Aziz Muhammad al-Wakil (Beirut: Dar al-Fikr, n.d.). Mizan, 1997).

${ }^{52}$ Alwi Shihab, Islam Inklusif: Menuju Sikap Terbuka dalam Beragama (Bandung: 
Fajar Syarif

of other religions outside of Islam such as Jews, Christians, Hindus, and Buddhists will go to heaven as well when they surrender to the Almighty. ${ }^{53}$

c. Pluralism

Pluralism is a view and attitude that believes that all religions have the truth and therefore also have the opportunity to give safety. ${ }^{54}$ Pluralism is not interpreted as a uniformity of religions, but an acknowledgment that outside the religion we believe is the right of other religions to obtain truth and salvation. Pluralism is also not synonymous with relativism, a view that relativizes all religious truths. ${ }^{55}$

Thomas Banchoff mentions that pluralism theologically implies harmony, convergence and the suitability of many values of religions. Thus, theologically, religious pluralism is the opposite of exclusivism. While in a sociological perspective, the word pluralism refers to the understanding of the diversity

${ }^{53}$ In addition to stating that religion outside Islam also has truth and salvation, Cak Nur also often mentioned the opinion of Rasyid Ridha, an Egyptian reformist who states that outside of Jews and Christians there are also Abl al-Kitab such as followers of Majusi, Buddhism, Hinduism, and Confucianism. See Nurcholish Madjid, Islam Agama Peradaban: Membangun Makna dan Relevansi Doktrin Islam dalam Sejarah (Jakarta: Paramadina, 1995), 81 84. Even Cak Nur also often mentioned that Abdul Hamid Hakim, a reformist figure of West Sumatra who stated that Hinduism, Buddhism, Chinese, and Japanese Religion besides being Abl al-Kitab, are also religions whose core teachings stem from the teachings of tawhid. See Nurcholish Madjid, Islam Doktrin dan Peradaban: Sebuah Telaah Kritis Tentang Masalah Keimanan, Kemanusiaan, dan Kemodernan (Jakarta: Paramadina, 1992), xxii. Beside that, a number of studies previously assessed that the practice of sufism in Islam partly also took elements of other religions including elements of mysticism in Hinduism. For example, monism Abu Yazid which later developed in Islamic sufism was influenced by elements of Indian Hinduism. See Robert C. Zaehner, Hindu and Muslim Mysticism (London: Athlone Press, 1960), vi.

${ }^{54}$ In The Oxford Dictionary of World Religion, pluralism is defined as follows: "Pluralism is a view, important in dialogue, that religious are diverse ways of leading the same ultimate truth and reality. All religions are corrigible and approximate ways of talking about the Absolute that cannot be described in human language." John Browker (ed.), The Oxford Dictionary of World Religion (Oxford: Oxford University Press, 1997), 756.

${ }^{55}$ Alwi Shihab, Islam Inklusif: Menuju Sikap Terbuka dalam Beragama (Bandung: Mizan, 1997), 42. 
of different religious traditions found in the same social and cultural space. ${ }^{56}$

Regarding the reality of the plurality of religious expressions, Khaled Abou El Fadl gave the following statement, "Meaning of the text is often as moral as its reader." ${ }^{27}$ In another sense it can be stated that one's religious expression will influence the way he understands his religion. If someone is exclusive, then the way his understanding and interpretation of religious teachings also tends to be exclusive. Likewise, if a person is inclusive from the start, he will also understand the teachings of religion inclusively. What is interesting is how actually religious adherents understand their religious teachings related to the existence of others. ${ }^{58}$ Religious views of other religions are also important to see considering that they reflect the part of the world view of the local community. ${ }^{59}$

The Qur'an ${ }^{60}$ has stated that Islam has several basic principles related to the existence of religious followers. First, diversity or plurality of religion is a necessity, something that is taken for granted. ${ }^{61}$ Second, in responding to the plurality of

${ }^{56}$ Thomas Banchoff, Religious Pluralism, Globalization, and World Politic (Oxford: Oxford University Press, 2008), 4.

${ }^{57}$ Khaled Abou El Fadl, The Place of Tolerance in Islam (Boston: Beacon Press, 2002), 23; Khaled Abou El Fadl, Speaking in God's Name: Islamic Law, Authority, and Women (Oxford: Oneworld Publication, 2001).

${ }^{58}$ Rhys H. William, "The Language of God in the City of Man: Religious Discourse and Public Politics in America", in Corwin Smidt (ed.), Religion as Social Capital: Producing the Common Good (Waco, Texas: Baylor University Press, 2003), 171-190.

${ }^{59}$ Learning this kind of understanding will not only be useful to see how the integration process takes place, but at the same time it is useful to gather information about the possibility of conflicts that are sometimes detected through cultural articulation and contestation among religious followers. For more information, see Marc Howard Ross, Cultural Contestation in Ethnic Conflict (New York: Cambridge University Press, 2007), 17.

${ }^{60}$ Q.S. al-Baqarah [2]: 139 and 256; Q.S. an-Nisa' [4]: 59; Q.S. al-Ma'idah [5]: 48; Q.S. Yunus [10]: 99; Q.S. Hud [11]: 118; Q.S. al-Kahfi [18]: 29; Q.S. al-Haji [22]: 17; Q.S. al-Hujurat [49]: 12.

${ }^{61}$ Muhammad 'Imarah, at-Ta'addudiyah: ar-Ru'yah al-Islamiyyah wa at-Tahaddiyah alGharbiyyah (Mesir: Dar an-Nahdah, 1997), 4. 
religions, Muslims are asked to respect each other and not insult each other and defame other people's religion or beliefs. Third, judgment about salvation on a belief is God's prerogative right, not human authority. Fourth, humanity is commanded to help each other, respect others because in truth they are worshiping the same God.

The information above explains to us that religious expression among religious followers can influence patterns of integration and conflict. The religious expression of the adherents will increase and become a trigger of conflict when it relates to the factors of economic and political inequality both locally, nationally and even the constellations that were originally reasonable in the community, then strengthen and become clear especially in the community so that it can cause conflict.

\section{Social Integration in Religious Adherents}

Social integration is a social process, in which each social component is oriented towards unification. M. Atho Mudzhar interpreted social integration as a process or potentiality that push towards a process in which the components of two or more social groups become integrated, thus giving togetherness and unity among existing groups. ${ }^{62}$

Social integration is also interpreted as a social volunteerism that accepts diverse individuals or groups to be actively involved in all social activities. With this perspective integration requires the principles of inclusion (accepting a variety of societies and incorporating them in an order); recognition (recognition of the existence of all members of society); and participation (active involvement of all community members).$^{63}$

${ }^{62}$ M. Atho Mudzhar, Pendekatan Studi Islam dalam Teori dan Praktek (Yogyakarta: Pustaka Pelajar, 2007), 129.

${ }^{63}$ Rita Pranawati and Irfan Abubakar (ed.), Kebebasan Beragama dan Integrasi Sosial 
From this explanation it can be concluded that social integration is a process of social interaction that takes place towards social unity. This process can occur when each member of the group is different and gives him the opportunity to participate in broader social interactions.

In the context of the relationship between religious followers that integration can take place when all religious followers develop a bond of citizenship. Ashutosh Varshney stated that cohesion or integration between religious followers can occur when there is civic engagement in citizenship. ${ }^{64}$ Conversely, conflict will occur when there are no citizenship bonds that are built.

Furthermore, Varshney distinguishes two citizen bonds, namely "associational" and "quotidian". ${ }^{65}$ Associational is a bond of cross-ethnic citizens such as business associations, professional groups, political parties, sports clubs, and others. Whereas quotidian is a simple bond that is routine, but not organically coordinated. Activities that are categorized in this type are for example visiting each other, eating together, going to parties together, and letting children play with other ethnic groups. If these two bonds are strong, they will be able to maintain social harmony, but if both do not go well, they will potentially trigger communal violence. Of these two bonds, continued Varshney, associational bond proved to be stronger than quotidian in maintaining peace especially when facing polarization by politicians. ${ }^{66}$

Varshney's thesis was criticized by Zahir Janmohamed who considered there are four Varshney mistakes in drawing conclusions.

(Jakarta: CSRC UIN Jakarta, 2011), xix.

${ }^{64}$ Ashutosh Varshney, Ethnic and Civic Life: Hindus and Muslims in India (New Haven and London: Yale University Press, 2002), 11.

${ }^{65}$ Varshney, 12.

${ }^{66}$ Varshney explicitly stated that informal and daily citizenship communication might be strong enough to maintain social cohesion in the countryside but inadequate in cities. Formal associational citizenship bond is needed to create inter-ethnic peace in urban areas. See Ashutosh Varshney, Ethnic and Civic Life: Hindus and Muslims in India (New Haven and London: Yale University Press, 2002), 52. 
First, over systematic where Varshney since the beginning of the study has generalized analysis for cities that do have different characteristics. Second, the conclusion that conflict is growing larger when becoming communal conflicts ignores the fact that there is fear in some Indian communities. Janmohamed gave an example of the violent conflict that took place in Bombay in 1992, in which many leather shoe factories belonging to Muslims were burnt which must be seen as a struggle for profit. Third, Varshney ignores the fact that communalization in India is caused more by fundamentalist groups. Fourth, simplifying the conflict between Hindus and Muslims as communal conflict, as well as simplifying that conflict in the Middle East is only a matter of Muslim-Jewish conflict. ${ }^{67}$

Apart from the debate above, it can be said that the existence of civic engangement, whatever its type is proven to be able to maintain social integration. In other terms, the existence of citizenship bonds is able to minimize the potential for conflict between religious followers. Conflicts between followers of religion will be easily muted by the existence of religious ties. On the contrary, there will be no increasingly sharp conflict when there are still ethnic or regional bonds between members involved in the conflict.

The concept of social assets developed by Coleman ${ }^{68}$ and Putnam $^{69}$ is by providing a point of view that is beneficial for strengthening social integration that is built by religious followers. Experts distinguish the existence of two social assets; social assets that enable strengthening of internal ties of religious followers; and social assets associated with efforts to build relationships with the wider social system. The first type is more of an internal strengthening of religious followers. Whereas the second will enable

\footnotetext{
${ }^{67}$ Zahir Janmohamed, "Review: Ethnic and Civic Life: Hindus and Muslims in India”, The American Journal of Islamic Social Sciences 21, no. 1 (2004): 122-124. 1990).

${ }^{68}$ J.S. Colemen, Foundation of Social Theory (Cambridge: Harvard University Press,

${ }^{69}$ Robert D. Putnam, Making Democracy Work: Civic Tradition in Modern Italy (Princeton, NJ: Princeton University Press, 1993).
} 
every follower to develop bonds with followers of other religions and in turn can build wider social integration. There are two very typical terms in the study of social assets namely "bonding" and "bridging". Bonding refers more to the formation of ties to internal followers of religion. While the second is the bond of citizenship that exists between religious followers. Both of these terms are similar to Varshney's conception. ${ }^{70}$

Thus the issue of social integration requires a broader platform in common than primordial identities (ethnicity, religion, and region). In the context of nationality, in fact various kinds of differences do not become a breakdown factor, resulting in conflict. The conflict still exists, because it is always present. But the community is able to manage it so that positive energy towards integration. The requirement is, of course, that an inclusive attitude, recognition of religious adherents and participation is needed. ${ }^{71}$ While participation can be realized when religious adherents have trust in others. Trust is the key for every believer to cooperate. Trust, as expressed by Putnam, ${ }^{72}$ is an important element as social capital in addition to the norms of reciprocity and civic networks.

The emergence of trust by itself will be the basis for the presence of awareness to develop cooperation, participation in the formation of civic ties more broadly. ${ }^{73}$ Trust is a fundamental element in the bond between believers. It is true that Putnam said

${ }^{70}$ Roger V. Patulny and Gunnar Lind Haase Swndsen, "Exploring the Social Capital Grid: Bonding, Bridging, Qualitative, Quantitative”, International Journal of Sociology and Social Policy 27, no. 1 (2007): 32-57.

${ }^{71}$ Ahmad Tsabit, at-Ta'addudiyah as-Siyasah (Kairo: al-Haiah al-Mishriyah al'Ammah li al-Kitab, 1990), 16.

${ }^{72}$ Robert D. Putnam, Making Democracy Work: Civic Tradition in Modern Italy (Princeton, NJ: Princeton University Press, 1993), 167.

${ }^{73}$ A research revealed a fact that the level of trust of Hindus towards Muslims is higher than that of Muslims towards Hindus. Only unfortunately, this study also found no convincing evidence regarding the relationship between religious allegiance and level of trust or trust worthiness. See Olaf Johansson Stenman, Minhaj Mahmud, and Peter Martinsson, "Trust and Religion: Experimental Evidence from Bangladesh", Keele Economics Research Papers, 10/2006. 
that trust lubricates social life. ${ }^{74}$ Inglehart ${ }^{75}$ and Saiful Mujani ${ }^{76}$ stated that mutual trust between fellow citizens is related to the overall heritage of human history, including economic, political, religious and other factors.

Particularly for religious elements, Inglehart noted that differences in religious traditions are the cause of differences in mutual trust between citizens. Through surveys in many countries, Ingehart made very surprising conclusions. According to him, the level of trust between citizens in the community influenced by Protestant and Confucian traditions was higher compared to people influenced by Catholicism and Islam. He further strengthened his findings, stating that the low level of trust among citizens in the Catholic tradition-influenced environment was low due to the hierarchical authority and religious leadership in it. A very rigid religious leadership model on Catholicism that emphasized a rigid relationship between the center of authority and followers tended to create a low level of mutual trust among citizens. ${ }^{77}$

Logically, it can be assumed that the level of trust of citizens among Hindus is also low. Remembering religious authority and hierarchy is also very strong in the Hindu tradition. In this religious tradition, not all followers can freely practice their religion without the guidance of religious leaders. Not to mention the added caste system (Brahmana, Knight, Vaishya, and Sudra) which is still used in society which influences their relationships and mutual trust. But

${ }^{74}$ Robert D. Putnam, Making Democracy Work: Civic Tradition in Modern Italy (Princeton, NJ: Princeton University Press, 1993), 3; Francis Fukuyama, Trust: the Social Virtues and the Creation of Prosperity (New York: Simon and Schuster, Free Press Paperbacks, 1995).

${ }^{75}$ Ronald Inglehart, “Trust, Well-Being, and Democracy”, in Mark E. Warren (ed.), Democracy and Trust (Cambridge: Cambridge University Press, 1999), 88.

${ }^{76}$ Saiful Mujani, Muslim Demokrat: Islam, Budaya Demokrasi, dan Partisipasi Politik di Indonesia Pasca Orde Baru (Jakarta: Gramedia Pustaka Utama, 2007), 121.

${ }^{77}$ Ronald Inglehart, “Trust, Well-Being, and Democracy”, in Mark E. Warren (ed.), Democracy and Trust (Cambridge: Cambridge University Press, 1999), 92-93. 
is that really true? Before answering this fundamental issue, look at the Inglehart's explanation regarding the Islamic religious tradition.

Inglehart's cross-country survey showed that the level of trust among citizens in Muslim-majority countries such as Turkey, Bangladesh, Azerbaijan, and Nigeria was very low. ${ }^{78}$ Unfortunately Inglehart did not explain further why this happened.

Further explanation was given by Saiful Mujani. Mujani in his survey criticized Inglehart's findings above. The link between religious traditions and trust among fellow citizens was something that involved many factors. The degree of trust between citizens was not solely determined by religious traditions but was strongly related to ongoing economic and political conditions.

Trust among citizens is a prerequisite for the emergence of reciprocity and allows them to develop network built by the followers of different religions. Not only from one religion. The network among religious followers will be more effective when it is developed towards social institutions which, according to Varshney's term, are referred to as associational bonds or social organizations. Social organizations that cross primordial boundaries (religion, ethnicity, region, etc.) will function as social bridges to manage conflict. With the existence of the social organization, a number of obstacles to social integration can be minimized. Barriers can start from suspicion (prejudice), stereotypes, and various other hidden transcripts.

The existence of social organizations is one proof of the birth of civic culture. In the research conducted by the LIPI team, it was stated that the high culture of citizenship in one area proved

${ }^{78}$ In the World Value Survey conducted by Inglehart, the proportion of people who claimed to believe in others was only $20 \%$. This means that less than 2 out of 10 people who were in Muslim-majority countries could trust others. This condition was almost the same as what happened in Indonesia, in the 2001 and 2002 survey it turned out that only 1 in 10 Indonesian people claimed to be able to trust others. See Saiful Mujani, Muslim Demokrat: Islam, Budaya Demokrasi, dan Partisipasi Politik di Indonesia Pasca Orde Baru (Jakarta: Gramedia Pustaka Utama, 2007), 125-126. 
to be influential in creating peace in the area. On the contrary, the low cultural citizenship causes a region to be prone to conflict. ${ }^{79}$ The existence of social organizations will be very meaningful for conflict resolution efforts.

\section{Conclusion}

Religious conflicts that occur violently and sustainably are usually caused by vested interests that go into and on behalf of religious teachings. If this element of hidden interest has entered into a conflict under the guise of religion, it cannot be expected that the conflict will end. Religious expression among religious followers can influence patterns of integration and conflict. It will increase and become a trigger for conflict when it relates to the factors of economic and political inequality both locally, nationally and even the constellation that is originally reasonable in the community, then strengthens and becomes clear, especially in society so that conflicts arise. Social integration can be a conflict resolution if maintained through bonds among citizens and social organizations that cross primordial boundaries (religion, ethnicity, region, etc.). All of that will function as a social bridge for managing conflict. With the existence of the social organization, a number of obstacles to social integration can be minimized. Barriers can start from suspicion (prejudice), stereotypes, and various other hidden transcripts. The existence of social organizations is one proof of the birth of civic culture.

${ }^{79}$ The civic culture in the LIPI team's research is interpreted as a set of values and behaviors that reflect the awareness of individuals and society as citizens. Citizenship culture is characterized by active participation, solidarity, mutual trust, tolerance, institutionalized norms of reciprocity, equality, and the establishment of social networks. See Muhammad Hisham, et al., Budaya Kewargaan Komunitas Islam di Daerah Aman Konflik (Jakarta: LIPI Press, 2007), 11-13. 


\section{REFERENCES}

Abdullah, M. Amin. Islamic Studies di Perguruan Tinggi: Pendekatan Integratif-Interkonektif. Yogyakarta: Pustaka Pelajar, 2006.

Abu-Nimer, Mohammed. Non Violence and Peace Building in Islam: Theory and Practice. Florida: University Press of Florida, 2003.

Armstrong, Karen. Campassion: 12 Langkah Menuju Hidup Berbelas Kasih. Bandung: Mizan, 2013.

Anderson, Benedict. Imagined Communities: Reflections on the Origins and Spread of Nationalism. London and New York: Verso, 1991.

Appleby, R.S. The Ambivalence of the Sacred: Religion and Violence, and Reconciliation. New York: Rowman and Littlefield, 2000.

Arkoun, Muhammad. al-Islam: al-Akblaq wa as-Siyasah. Beirut: Markaz al-Inma’ al-Qaumi, 1990.

'Ashur, Muhammad Mahdi. at-Ta'addudiyah al-Ithniyah: Idarah asSira'at al-Istirajiyat at-Taswiyah. Oman: al-Markaz al-'Ilmi li ad-Dirasat as-Siyasiyah, 2002.

Badan Penelitian dan Pengembangan Departemen Agama RI. Manajemen Konflik Umat Beragama. Jakarta: Proyek Peningkatan Kerukunan Hidup Umat Beragama dan Pusat Kerukunan Beragama Departemen Agama RI, 2003.

Banchoff, Thomas. Religious Pluralism, Globalization, and World Politic. Oxford: Oxford University Press, 2008.

al-Banna, Hasan and Jamal al-Banna. at-Ta'addudiyat fi Mujtama' Islami. Kairo: Dar al-Fikr al-Islami, 2001.

Bertrand, Jacques. Nationalism and Ethnic Conflict in Indonesia. New York: Cambridge University Press, 2004.

Browker, John (ed.). The Oxford Dictionary of World Religion. Oxford: Oxford University Press, 1997. 
Burhanuddin, Jajat and Arif Subhan. Sistem Siaga Dini terhadap Kerusuban Sosial. Jakarta: Badan Penelitian dan Pengembangan Departemen Agama RI and PPIM, 2000.

Calhoun, Craig. "Nationalism and Civil Society: Democracy, Diversity, and Self Determination", in Craig Calhoun, Social Theory and The Politics of Identity. Oxford: Blackwell Publisher, 1998.

Church, F. Forrester. The Essential Tillich: an Anology of The Writings of Paul Tillich. Chicago: University of Chicago Press, 1987.

Colbran, Nicola. "Realities and Challenges in Realising Freedom of Religion or Belief in Indonesia", The International Journal of Human Rights 14, no. 5 (2010): 678-704.

Colemen, J.S. Foundation of Social Theory. Cambridge: Harvard University Press, 1990.

Coppel, C.A. Violent Conflicts in Indonsia: Analysis, Represntation, Resolution. London: Routledge, 2005.

Dahrendorf, Rafl. Class and Class Conflict in Industrial Society. Stanford: Standford University Press, 1959.

Dawkins, Richard. The God Delusion. Orlando: Houghton Mifflin Harcourt, 2008.

Demartoto, Argyo. "Strukturalisme Konflik: Pemahaman Akan Konflik pada Masyarakat Industri Menurut Lewis Coser dan Rafl Dahrendrof”, Jurnal Sosiologi Dilema 24, no. 1 (2010): 192-223.

El Fadl, Khaled Abou. Speaking in God's Name: Islamic Law, Authority, and Women. Oxford: Oneworld Publication, 2001.

. The Place of Tolerance in Islam. Boston: Beacon Press, 2002.

Fisher, Simon. Working With Conflict: Skills and Strategies for Action. London: Zed Books, 2000. 
Fukuyama, Francis. Trust: the Social Virtues and the Creation of Prosperity. New York: Simon and Schuster, Free Press Paperbacks, 1995.

Grim, Brian J. "Law and Social Conflict in the $21^{\text {st }}$ Century: Findings from Sociological Research", Oxford Journal of Law and Religion 1, no. 1 (2012): 249-271.

Grose, George B. and Benjamin J. Hubbard (eds.). The Abraham Connection: a Jew, Christian, and Muslim in Dialoge. Notre Dame: Cross Cultural, 1994.

Habermas, Jurgen. Between Naturalism and Religion. New York: Polity Press, 2009. Religion in Public Sphere. New York: Polity Press, 2009.

Hanafi, Hasan. Dirasat Islamiyah. Kairo: Maktabah al-Anjilu alMishriyah, n.d.

Hardiman, F. Budi. Demokrasi Deliberatif. Yogyakarta: Kanisius, 2009. . Ruang Publik: Melacak Partisipasi Demokratis dari Polis sampai Cyberspace. Yogyakarta: Kanisius, 2010.

Harris, Sam. Letter to a Christian Nation. New York: Vintage Books, 2008.

. The End of Faith: Religion, Terror, and the Future of Reason. Ohio: W.W. Norton and Company, 2004.

Heiler, Frederich. Prayer: a Study in the History and Psychology of Religion. Oxford: Oxford University Press, 1932.

Hidayat, Komaruddin and Muhammad Wahyuni Nafis. Agama Masa Depan: Perspektif Filsafat Perenial. Jakarta: Paramadina, 1995.

Hisham, Muhammad, et al. Budaya Kewargaan Komunitas Islam di Daerah Aman Konflik. Jakarta: LIPI Press, 2007.

Hitchens, Christopher. God Is Not Great: How Religion Poisons Everything. New York: Grand Central Publishing, 2007. 
Fajar Syarif

Illich, Paul T. The Spiritual Situation in Our Technical Society. Georgia: Mercer University Press, 1988.

'Imarah, Muhammad. at-Ta'addudiyah: ar-Ru'yah al-Islamiyyah wa atTahaddiyah al-Gharbiyyah. Mesir: Dar an-Nahdah, 1997.

Inglehart, Ronald. "Trust, Well-Being, and Democracy", in Mark E. Warren (ed.), Democracy and Trust. Cambridge: Cambridge University Press, 1999.

al-Jabiri, Muhammad 'Abid. Bunyat al-'Aql al-'Arabi: Dirasah Tabliliyah Naqdiyah li Nudhum al-Ma'rifah fi ats-Tsaqafah al-Arabiyah. Beirut: Markaz Dirasat al-Wihdah al-'Arabiyah, 1990.

Janmohamed, Zahir. "Review: Ethnic and Civic Life: Hindus and Muslims in India", The American Journal of Islamic Social Sciences 21, no. 1 (2004): 122-124.

Jati, Wasisto Raharjo. "Kearifan Lokal Sebagai Resolusi Konflik Keagamaan”, Walisongo 21, no. 2 (2013): 29-43.

Kalin, Ibrahim. "Mashadir at-Tasamuh wa 'Adam at-Tasamuh fi alIslam”, Majallah Adyan, 2009.

Kamil, Sukron, Noorhaidi Hasan, and Irfan Abubakar. Islam di Ruang Publik: Politik Identitas dan Masa Depan Demokrasi di Indonesia. Jakarta: Centre for the Study of Religion and Culture (CSRC) UIN Syarif Hidayatullah Jakarta, 2011.

Kimball, Charles. When Religion Becomes Evil. London: Harper Collins, 2003.

Klinken, Gery van. Communal Violence and Democratization in Indonesia: Small Town Wars. London: Routledge, 2007.

Lapidus, Ira M. A History of Islamic Societies. New York: Cambridge University Press, 1988.

Madjid, Nurcholish. Islam Agama Peradaban: Membangun Makna dan Relevansi Doktrin Islam dalam Sejarah. Jakarta: Paramadina, 1995. 
Islam Doktrin dan Peradaban: Sebuah Telaah Kritis Tentang

Masalah Keimanan, Kemanusiaan, dan Kemodernan. Jakarta:

Paramadina, 1992.

McLaughlin, Karrie and Ari Perdana. "Conflict and Dispute Resolution in Indonesia Information from the 2006

Governance and Decentralization Survey", Indonesian Social Development Paper, no. 16 (2010).

Mudzhar, M. Atho. Pendekatan Studi Islam dalam Teori dan Praktek.

Yogyakarta: Pustaka Pelajar, 2007.

Mujani, Saiful. Muslim Demokrat: Islam, Budaya Demokrasi, dan Partisipasi Politik di Indonesia Pasca Orde Baru. Jakarta: Gramedia Pustaka Utama, 2007.

Noer, Kautsar Azhari. "Agama Langit versus Agama Bumi: Sebuah Telaah atas Klasifikasi Agama-agama", Titik Temu: Jurnal Dialog Peradaban 3, no. 2 (2011): 72-96.

Nottingham, Elizabeth K. Agama dan Masyarakat: Suatu Pengantar Sosiologi Agama. Jakarta: Rajawali Press, 1990.

Panggabean, Rizal. Pola-pola Konflik Keagamaan di Indonesia (19902008). Jakarta: Paramadina, 2009.

Panikkar, Raimundo. The Intra-Religious Dialogue. Costa Mesa: Paulist Press, 1999.

Patulny, Roger V. and Gunnar Lind Haase Swndsen. "Exploring the Social Capital Grid: Bonding, Bridging, Qualitative, Quantitative", International Journal of Sociology and Social Policy 27, no. 1 (2007): 32-57.

Pranawati, Rita and Irfan Abubakar (ed.). Kebebasan Beragama dan Integrasi Sosial. Jakarta: CSRC UIN Jakarta, 2011.

Putnam, Robert D. Making Democracy Work: Civic Tradition in Modern Italy. Princeton, NJ: Princeton University Press, 1993. 
Qorib, Muhammad. "Pemikiran Ahmad Syafi'i Ma'arif Tentang Pluralisme Agama", Ph.D. Thesis, Universitas Islam Negeri (UIN) Syarif Hidayatullah Jakarta, 2012.

Rasmi, Sarah, Timothy M. Daly, and Susan S. Chuang, "Intergenerational Conflict Management in Immigrant Arab Canadian Families", Journal of Cross-Cultural Psychology 45, no. 7 (2017): 1.124-1.144.

Roberts, Keith A. Religion in Sociological Perspektive. Belmont: Wadsworth, 2004.

Ross, Marc Howard. Cultural Contestation in Ethnic Conflict. New York: Cambridge University Press, 2007.

Salmi, Ralph H., Cesar Adib Majul, and George Kilpatrick Tanham. Islam and Conflict Resolution: Theories and Practices. Lanham: University Press of America, 2001.

Shihab, Alwi. Islam Inklusif: Menuju Sikap Terbuka dalam Beragama. Bandung: Mizan, 1997.

Shonhaji. "Agama: Konflik dan Integrasi Sosial: Agama Jawa dalam Perspektif Clifford Geertz", al-Adyan: Jurnal Studi Lintas Agama 5, no. 1 (2010): 17-32.

Steenbrink, Karel. "Does Comparison Help? The Disastrous Decade of Yugoslavia Seen from an Indonesian Perspective", in Chaidar S. Bamualim, Communal Conflict in Contemporary Indonesia. Jakarta: The Centre for Languages and Cultures IAIN Syarif Hidayatullah Jakarta and The Konrand Adenauer Foundation, 2003.

Stenman, Olaf Johansson, Minhaj Mahmud, and Peter Martinsson. "Trust and Religion: Experimental Evidence from Bangladesh", Keele Economics Research Papers, 10/2006.

Suprapto. Semerbak Dupa di Pulau Seribu Masjid: Kontestasi, Integrasi, dan Resolusi Konflik Hindu-Muslim. Jakarta: Impressa, 2013. 
Suseno, Franz Magnis. "Underlying Factors of Conflict between Ethnic and Religious Groups in Indonesia: Prevention and Resolution", in Chaidar S. Bamualim, Communal Conflict in Contemporary Indonesia. Jakarta: The Centre for Languages and Cultures IAIN Syarif Hidayatullah Jakarta and The Konrand Adenauer Foundation, 2003.

Suseno, Franz Magniz, et al. Memahami Hubungan antar Agama. Yogyakarta: Elsaq Press, 2007.

asy-Syahrastani, Muhammad Abdul Karim. al-Milal wa an-Nihal, ed. Abdul Aziz Muhammad al-Wakil. Beirut: Dar al-Fikr, n.d.

Taher, Tarmizi. Menuju Ummatan Wasathan: Kerukunan Beragama di Indonesia. Jakarta: PPIM, 1998.

Tsabit, Ahmad. at-Ta'addudiyah as-Siyasah. Kairo: al-Haiah alMishriyah al-'Ammah li al-Kitab, 1990.

Tilley, Terrence W. Postmodern Theologies and Religious Diversity. Maryknoll, New York: Orbis Book, 1996.

Tohiriyyah, Raden Siti Fadilah. Konflik Muslim-Kristen: Studi Kasus Gereja Kristen Indonesia (GKI) Yasmin Bogor. Ciputat: Cinta Buku Media, 2016.

Toynbe, Arlnod. A Study of History. Oxford: Oxford University Press, 1987.

Varshney, Ashutosh. "Pattern of Collective Violence in Indonesia (1990-2003)", in United Nation Support Facility for Indonesian Recovery Report. Jakarta: Report UNSFIR, 2004. . Ethnic and Civic Life: Hindus and Muslims in India. New Haven and London: Yale University Press, 2002.

Vendley, Williem. "Kekuatan Agama-agama untuk Perdamaian", in Elza Peldi Taher, Merayakan Kebebasan Beragama: Bunga Rampai 70 Tabun Djohan Effendi. Jakarta: ICRP dan Kompas, 2009. 
Fajar Syarif

Weige, George. "Religion and Peace an Argument Complexified", in Syeryl Brown and Kimber Schraub, Resolving Third Word Conflict: Challenge for New Era. Washington DC: US Institute of Peace Press, 1992.

William, Rhys H. "The Language of God in the City of Man: Religious Discourse and Public Politics in America", in Corwin Smidt (ed.), Religion as Social Capital: Producing the Common Good. Waco, Texas: Baylor University Press, 2003.

Yusuf, Choirul Fuada. Konflik Bernuansa Agama: Peta Konflik Berbagai Daerah di Indonesia 1997-2005. Jakarta: Badan Penelitian dan Pengembangan Kementerian Agama RI, 2013.

Zaehner, Robert C. Hindu and Muslim Mysticism. London: Athlone Press, 1960. 